\title{
ARISTOTLE'S DEMOSTHENES, THE KILLING OF NICANOR, AND THE COMPOSITION OF THE RHETORIC
}

Chapter 23 of Book 2 of Aristotle's Rhetoric gives a catalogue of argumentative topoi or common topics, supported by examples. ${ }^{1} 2.23 .3(1397 \mathrm{~b} 7-9)$ accordingly gives us the following as an example of argument from correlatives ( $\dot{\varepsilon} \kappa \tau \tilde{\omega} \nu \pi \rho \grave{\varsigma} \varsigma \grave{\alpha} \lambda \lambda \eta \lambda \lambda \alpha)$ :

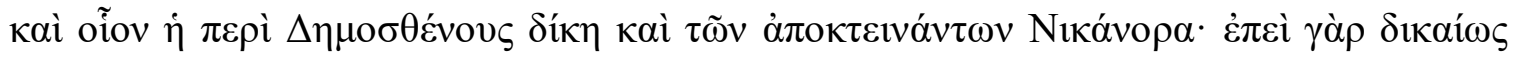

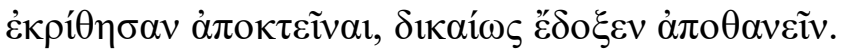

'Another example may be found in the trial of Demosthenes and those who killed Nicanor.

For since it was decided that they had justly killed him, it was thought that he had been justly put to death.'

Modern scholars have doubted that the 'Demosthenes' here should be identified with the fourthcentury orator of that name, some of them because we do not hear of this episode elsewhere in our

\footnotetext{
${ }^{1}$ For a detailed recent treatment of this chapter, see Rambourg (2014), 223-350 (especially 270-4 on argument from correlatives, i.e. Rhet. 1397a23-b11).

${ }^{2}$ Text: Kassel (1976) (as throughout). Translation: Freese (1926), 299, updated.
} 
sources for Demosthenes' life and public activity. ${ }^{3}$ In what follows, I indicate that there is no good reason why all three of the appearances of a 'Demosthenes' in the Rhetoric should not refer to the fourth-century orator; I then move (in Part II) to sketch what seems to me a plausible chronological context for the killing, namely the second half of $323 \mathrm{BC}^{4}$ or early 322 , around or after the outbreak of the Lamian War. In Part III, I consider how this proposed dating may intersect with our understanding of the Rhetoric's composition and, in particular, offer some support for the idea that this part of Book 2 was either composed by Aristotle very late, or - more likely - reached its present form after his death. If so, any 'final' date for the Rhetoric must be thought of as either beyond obvious reach or as belonging at least some fifteen years later than usually envisaged.

We do not hear of the episode of 'Demosthenes and the killers of Nicanor' anywhere else, but this fact carries little independent weight. The way the Rhetoric mentions it does not even guarantee that it would deserve to be recalled elsewhere: the dead Nicanor may have been an important figure (as I go on to suggest later), but our contemporary sources are mainly oratorical, referring to events external to a given case only when useful (or necessary) for that case or the broader issues at hand, so we end up with only a partial grasp of political events. As far as Demosthenes was concerned, the charges against him, or the allegations of his involvement, could have been trumped-up, and, given that we do not know how Nicanor's 'killers' came to be in court,

\footnotetext{
${ }^{3}$ See e.g. Cope (1877), 2.244; Düring (1966), 118 n. 2; Grimaldi (1988), 298; Trevett (1996), 3712; Rapp (2002), 2.753; Chiron (2007), 380 n. 16; Kennedy (2007), 173 n. 135. Some scholars see the episode as too compressed for further interpretation: see e.g. Rambourg (2014), 273-4.

${ }^{4}$ All dates in this article are BC.
} 
this could (just possibly) have been true of them too. ${ }^{5}$ Nor does the Rhetoric's phrasing suggest that the matter was contentious; we are left to assume Demosthenes and the 'killers' were acquitted. In Demosthenes' own case, there are two loose parallels available: the allegation made by Aeschines (in 343 and 330) and by a client of Dinarchus (in 323) that Demosthenes had previously been involved in the murder of Nicodemus of Aphidna; ${ }^{6}$ and, second, Aeschines' claim in 330 that Demosthenes had been personally involved in the killing of Anaxinus of Oreus, who was arrested on a charge of spying for Philip in Athens (possibly in about 341 or 340 during the escalation of tension with Macedon prior to war) and apparently expired under torture. ${ }^{7}$

The killing of Nicanor could have taken a similar form to one of these episodes. Neither seems to have resulted in an actual prosecution of Demosthenes. ${ }^{8}$ Aeschines claims to have 'convicted' Demosthenes in an Assembly meeting for killing Anaxinus unlawfully, but this is

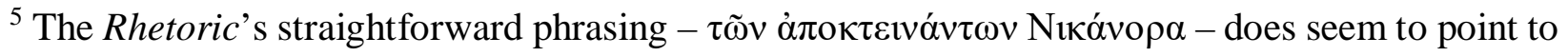
their having been caught red-handed (or similar), or to their being more 'officially-sanctioned' 'killers'; alternatively, it may be working with the version of Nicanor's death that prevailed after the trial was concluded: i.e. that the defendants did kill him, but did so justly.

${ }^{6}$ Demosthenes is implicated in it by Aeschines $(1.170-3$ and $2.148,166)$ and Dinarchus $(1.30,47)$, and denies it in Against Meidias (21.104-7, 116-22); see further Fisher (2001), 316-18.

${ }^{7}$ Aeschin. 3.223-5; Demosthenes' riposte: D. 18.137. For a c. 341 date: Schaefer (1885-7), 2.494 and Carey (2000), 240 n. 255.

8 Though Nicodemus' likely murderer, Aristarchus, was certainly tried and exiled (Aeschin. 2.166), and there may be an indication here that Demosthenes defended him at his trial. 
much more likely to be metaphorical than to relate to an actual legal charge. ${ }^{9}$ But these examples do give a sense of the kind of vivid defamatory material that could be fashioned in this period for liberal use against litigants who were also prominent politicians. We know that Demosthenes, like other anti-Macedonians, was frequently the target of politically-motivated prosecutions during the post-Chaeronea period down to 335 , and beyond. ${ }^{10}$ The bases of most of these attacks have not made it into the tradition in detail, presumably because at least some of them were tenuouslyfounded and/or opportunistic; but when we hear (albeit from his own pen) that Hyperides, Demosthenes' then-ally, was indicted three separate times in one day by Diondas in the aftermath of Chaeronea, ${ }^{11}$ this should encourage a sceptical view of the typical amount of independent substance in many charges against anti-Macedonians that made it to court between 338 and 323. Nicanor's killing may have belonged in a similar category, at least as far as any specific charge against Demosthenes went, so it is unclear whether we should expect to hear of it in the sources.

We know of two other relevant orators named Demosthenes, both Athenian. One is the fifth-century general, who has a notoriously limited traditional profile as an orator (though he must have been a competent one). ${ }^{12}$ The other is Demosthenes son of Democles of Lamptrae, unattested

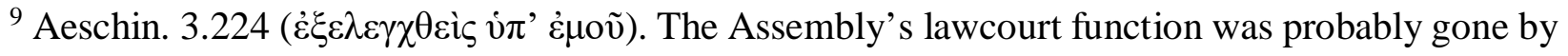
the late 340s: Hansen (1999), 158-9.

${ }^{10}$ D. 18.249-50, 322; cf. Hyp. Diond. 9 Horváth; Hyp. Dem. 28; Plut. Dem. 21.1-2.

${ }^{11}$ Hyp. Diond. 9 Horváth.

${ }^{12}$ Roisman (1993), 51; Westlake (1968), 98-9.
} 
in literary sources but the proposer of two honorific decrees in the $320 \mathrm{~s} .{ }^{13}$ It would be hasty to identify either (or an unknown homonym) in the Rhetoric, though. Given the work's focus, it would be very surprising if a Demosthenes other than the famous orator were referred to without a demotic or some other sort of qualification; any reader would think of the famous orator first. ${ }^{14}$ In fact none of the three references to a Demosthenes in the Rhetoric carries any qualification. Furthermore, one of them indisputably refers to the famous Demosthenes: an example of the post hoc ergo propter hoc fallacy involving Demades blaming Athens's war with Philip on the policies

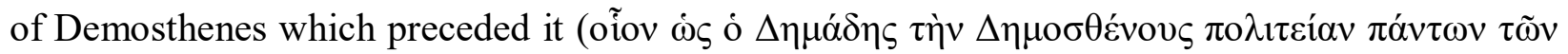

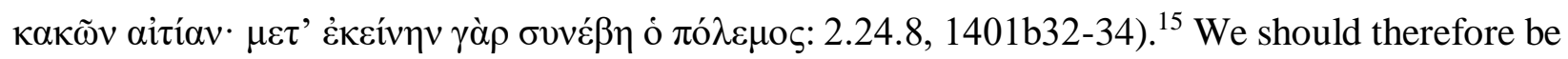
prepared to countenance other appearances, as there is apparently no policy of deliberate suppression at work. Beyond the Nicanor passage, the third 'Demosthenes' in the Rhetoric is a speaker who compared the Athenian demos to seasick passengers (Rhet. 3.4.3, 1407a5-6). ${ }^{16}$ The

${ }^{13} I G \mathrm{II}^{3} 355$, line 9 (of 329/8) and 367, line 5 (of 325/4); see also Worthington (2002), 23-4. If he were the correct Demosthenes, my suggestion below about the likely date of the killing of Nicanor would still be valid, given that the activity attested for this Demosthenes belongs to the 320s.

${ }^{14}$ By way of parallel, the Speusippus of Rhet. 3.10 .7 (1411a21-3) is distinguished from the

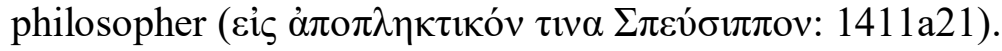

15 'Thus, Demades declared that the policy of Demosthenes was the cause of all the evils that happened, since it was followed by the war': Freese (1926), 333.

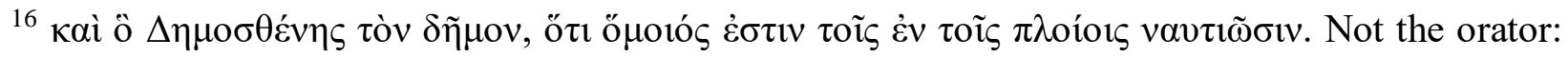
Cope (1877), 2.316, 3.52; Düring (1966), 118 n. 2, 121; Kennedy (2007), 206 n. 54, cf. 279 n. 37. The identification with the orator is upheld by Spengel (1867), 2.375-6 and Meerwaldt (1926), 
famous orator Demosthenes' public career began in 354 and therefore identifying him as the 'Demosthenes' here accords with arguments for the early date of Rhetoric Book $3 .{ }^{17}$ Nor should the very rarity of Demosthenes' appearances in the Rhetoric (whether on my view or on the usual view) worry us. Nothing required Aristotle to use Demosthenes as an example. Mid-fourth-century Athens was full of skilled and quotable orators, as the Rhetoric itself valuably reminds us. We should therefore prefer the simple conclusion that the famous orator, Aristotle's coeval, is meant in the Nicanor passage and in the simile about seasick passengers, just as he is in the reference to Demades' criticism of his policies.

\section{II}

If this is so, we can begin to locate a context for the trial of Demosthenes and Nicanor's killers. I assume that the name Nicanor is correct here - this has occasionally been doubted, but without good reason. ${ }^{18}$ The name is common in the fourth century, as in general. ${ }^{19}$ This rightly invites

368-9, and thought likely by Trevett (1996), 371. Demosthenes uses similar nautical imagery of the demos elsewhere (e.g. 19.136, admittedly focalized through his pro-Macedonian opponents).

${ }^{17}$ Rapp (2002), 1.182. Further on the separateness of Book 3: e.g. Düring (1966), 118, 121-5; Fortenbaugh (1996), 171-3; Chiron (2007), 50-1, and 55 for the early date.

${ }^{18}$ For example by Spengel (1867), 2.297 and Meerwaldt (1926), 349-56. It is unlikely that Aristotle or a successor would have made this mistake with a name so closely linked to Aristotle's own biography. Nicodemus also only ever has one murderer in the oratorical passages: Aristarchus.

${ }^{19}$ Volumes I-VB of $L G P N$ list a total of 529 individuals across periods. 
caution. It is worth pointing out, though, that a sizeable proportion of the fourth-century Nicanors listed in the Lexicon of Greek Personal Names are Macedonians or northern Greeks within the immediate Macedonian sphere of influence: 25 out of 41 individuals. ${ }^{20}$ It is therefore likely that we are dealing with a Macedonian or northern Greek (even if not necessarily one we already know of, of course), even without considering that our Nicanor might be one of the several important Macedonian officials known from literary sources. ${ }^{21}$ The next thing to note is that a key feature of the Nicanor passage in the Rhetoric is the sanction the jury apparently gave to Nicanor's killing, in taking the view that he was killed justly. It is true that we could be dealing with a matter of purely private interest - on the model of Demosthenes' alleged complicity in the murder of Nicodemus, mentioned above. But Demosthenes' involvement (whether naturally in the circumstances or because he was 'dragged in' by hostile prosecutors) might equally indicate that the Nicanor case had wider significance. The fact that only a relatively small number of known instances of the name come from Athens (18 out of 529 in $L G P N$, only three of which date to the

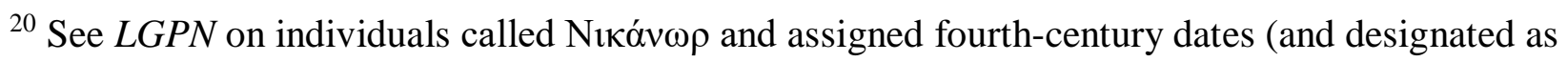
'iv/iii' BC. If those designated 'hell[enistic]' are included, the proportion is still notable: 25 out of 48). Under 'Macedonian and northern Greek' I include individuals called Nicanor listed in $L G P N$ under Macedonia (14), Amphipolis (1), Mieza (1), Heraclea Lyncestis (2), Dion (1), Thasos (1),

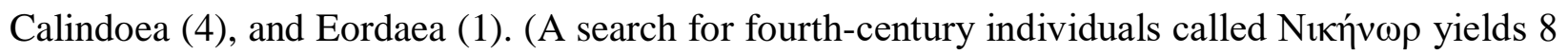
entries from Thasos, with 2 others outside the area of interest.)

${ }^{21}$ Heckel (2006), 176-8 lists twelve key figures, Berve (1926), 2.274-8 nine; see also Tataki (1998), 175, 380-4. Sorting them all out is difficult: see e.g. Bosworth (1994); Heckel (2007). I make no claims below for identifying Aristotle's Nicanor with any other apart from the envoy. 
fifth or fourth century) may, in addition, push slightly against any presumption that what we have here is some sordid local incident involving otherwise unknown Athenians. Indeed, the fact that Demosthenes' and Nicanor's names are not glossed in any way may itself suggest an affair of some notoriety, involving important people, which a later reader might be aware of.

This can encourage us to think of chronological contexts within the period of Demosthenes' maturity (366-322) where an Athenian jury might have been more likely than at other times to agree that a Macedonian had been justly killed. The immediate period of war between Philip and the Athenian alliance from 339 to 338 is clearly an option; the killing of Nicanor may have been a 'quasi-official' business along the same lines as the case involving the 'spy' Anaxinus, which may well belong to that context. Another possibility is the period around or after the outbreak of the Lamian War in later 323. This avenue looks particularly promising for two reasons.

First, as noted above, many scholars have doubted that the Demosthenes in the Nicanor passage can be the famous orator because the details of his biography are well-known. But the lineaments of Demosthenes' biography, ancient and modern, derive above all from the details of his speech texts and those of his rivals, and these peter out in early 323 with the Harpalus trials. ${ }^{22}$ In addition, those of Demosthenes' Letters which are likely to be genuine all seem to belong chronologically before the outbreak of the Lamian War, with the exception of the very short Sixth Letter. ${ }^{23}$ So if Nicanor was killed, and Demosthenes implicated, between early 323 and autumn 322 when Demosthenes fled Athens, it is hard to know where we could be sure of hearing about it

\footnotetext{
${ }^{22}$ The only extant speech which belongs later than this is Hyperides' fragmentary Funeral Oration of early 322, where contemporary, living personalities would be unlikely to intrude.

${ }^{23}$ Worthington (2006), 99 (and 133 for the authenticity of the Sixth Letter).
} 
- and that is even without considering that the charge might have been trumped-up and the case an open-and-shut one, at least where Demosthenes' involvement was concerned, with the result that it made unpromising material for development by rivals and biographers. One of the prosecution speeches from the Harpalus trials, Dinarchus' Against Demosthenes, though, would be highly likely to bring up an item like this, however tenuous Demosthenes' connection with it; Dinarchus' aim in that speech was to cast aspersions on Demosthenes from as many angles as possible. For example, the speech makes free with the Nicodemus affair despite the fact that this had taken place between two and three decades earlier. If we do not hear of the Nicanor business in Against Demosthenes, then, this may be an indication that Nicanor was killed later. ${ }^{24}$

The second reason to think seriously about a context around or after the outbreak of the Lamian War is that it might yield us a plausible candidate for the dead Nicanor, namely the Nicanor who came as envoy to the Olympic Games in the summer of 324 to make an official announcement of Alexander's Exiles Decree. ${ }^{25}$ The main reason to think of this Nicanor is that we know (from

${ }^{24}$ Against Demosthenes will have been revised, pushing our text's 'real' date somewhat later than early 323 . However, as it is the work of a professional logographer, who would have been issuing speeches to advertise and so presumably motivated to revise and circulate at an efficient pace (especially in the case of a speech which helped convict a high-profile orator), this may have happened while Demosthenes was still absent, and before the hypothetical killing of Nicanor.

${ }^{25}$ Literary sources: Hyp. Dem. 18; D. S. 17.109.1-2, 18.8.2-7; Curtius 10.2.4-7; [Plut.] Mor. 221a; Justin 13.5.2-6. Of these, only Hyperides and Diodorus name the bearer, though we can safely add Din. 1.81-2, 103. See further: Bosworth (1988), 220-8; Worthington (2015). 
Dinarchus) that Demosthenes came to Olympia specifically to hold private talks with him. ${ }^{26}$ So if Nicanor the envoy was killed or met a quasi-official end (by analogy with the case of the 'spy' Anaxinus) in a suitable context after his mission to Olympia (i.e. between the summer of 324 and the autumn of 322), Demosthenes could easily have been a target for accusations of some sort of involvement with it, launched by his political opponents, as we saw in the two earlier cases.

An obstacle here is that Nicanor the envoy is usually identified with Nicanor of Stageira, Aristotle's prospective son-in-law (and executor). ${ }^{27}$ Düring is a notable but solitary exception to this consensus. ${ }^{28}$ If this Nicanor had died before autumn 322, Aristotle would have had to find a new executor, and we would probably know about that. But the identification of the envoy with Nicanor of Stageira is far from secure. One alternative is that there were two Nicanors of Stageira - possible given that the name is common. A second, which I prefer, is that Nicanor the envoy was not the man from Stageira at all. Neither of the contemporary sources for him - Hyperides and Dinarchus - call him Nicanor 'of Stageira' ${ }^{29}$ It is Diodorus and Harpocration who do so,${ }^{30}$ both

${ }^{26}$ Din. 1.81-2, 103; Bosworth (1988), 220; Worthington (2013), 312-15.

${ }^{27}$ Berve (1926), 2.276-7 (no. 557), followed by e.g. Worthington (1992), 251; Bosworth (1994), 57; Tataki (1998), 175 (no. 5); Whitehead (2000), 413 ('indubitably' the same); Heckel (2007), 401-2; Landucci Gattinoni (2008), 57; Natali (2013), 12-13.

${ }^{28}$ Düring (1957), 271.

${ }^{29}$ Din. 1.81-2, 103; Hyp. Dem. 18.

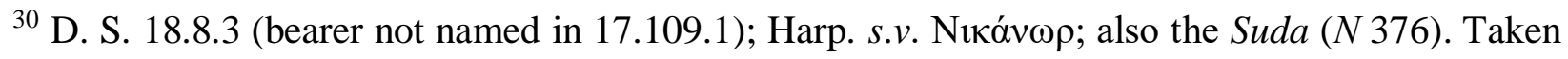
with the references in the footnote above, this group of three (out of six) hardly justifies Bosworth's claim that 'this Nicanor is repeatedly described as a native of Stageira': (1994), 58. 
of whom were operating much later and in contexts where biographical traditions about Aristotle had been circulating for a long time, offering manifold possibilities for confusion (for them and their sources). Diodorus quite often makes errors with the names or other personal details even of prominent individuals, and even when using good sources. ${ }^{31}$ So any easy association of Nicanors here is impossible, and the possibility can be entertained that we are dealing with two different men in the relative of Aristotle and the envoy.

The outbreak of the Lamian War in the summer of $323^{32}$ was a dramatic expression of antiMacedonian resentment at Athens. This resentment had recently led to diplomacy conducted with a view to collective action given the right opportunity, and was focused above all on the consequences of the Exiles Decree. ${ }^{33}$ The hypothetical killing of the former envoy Nicanor, and the jury's favourable view of his killers' action, would fit well in this context. If he was either in Athens or in a place accessible to Athenian killers (or people who would be tried at Athens), then Nicanor would have been vulnerable as the public face of the Exiles Decree in Greece and thus

31 Stylianou (1998), 138. The main source scholars traditionally identify for Book 18 is Hieronymus, but see Landucci Gattinoni (2008), xii-xxiv for critique. Errors introduced or perpetuated by Diodorus on the names and personal details of significant fourth-century figures (as opposed to his multiple errors on the names of annual sets of officials) can be found at (e.g.) 15.47.8, 15.59.1, and 15.82.6. One may result from a scribal error: Tuplin (1979), 347-51, 356-7. ${ }^{32}$ D. S. 18.9.4-10.4.

${ }^{33}$ Athenian resentment: Din. 1.82; D. S. 17.111.3-4 and 18.8.6-9.1 (with 18.8.1); Curtius 10.2.67; Justin 13.5.6. See especially Errington (1975); Ashton (1983), 51-2 (with n. 26 for earlier buildup in the 320s); Bosworth (1988), 225-7; Whitehead (2000), 414; Worthington (2015), 98-9. 
inescapably associated with it. ${ }^{34} \mathrm{We}$ have other evidence that Athens was an unpleasant place to be for Macedonians or those who could be associated with them at this time: later 323 saw Aristotle leave Athens for Chalcis, possibly to escape a politically-motivated impiety charge. ${ }^{35}$ Around or after the outbreak of war, then, an Athenian jury might well sympathize with a lawcourt orator's (perhaps Demosthenes' own?) construction of the envoy Nicanor's murder or killing (perhaps while engaged in activities which could be construed as suspicious, as with Anaxinus) as a symbolic counterstroke against repeated Macedonian encroachments on the terms of the League of Corinth (of which the Exiles Decree could easily be represented as a transparent and inarguable violation). ${ }^{36}$ The demos' decision to imprison en masse the captured Samian exiles who had attempted to force a return to Samos against the resistance of the Athenian cleruchs - and in due course to condemn them to death (even if they were ultimately rescued) - testifies to a popular appetite for vigorous measures shortly after (or shortly before) Alexander's death. ${ }^{37}$ There are also good fifth- and fourth-century examples of murders of representatives of other states directly consequent on, or prior to, the outbreak of war with that state or an outbreak of stasis where the

${ }^{34}$ See Heckel (2007), 402 n. 3 for the likely toxicity of this association in 323/2 Athens.

35 Aristotle's departure in 323/2: Düring (1966), 2 ('nicht später als im Frühjahr 322'); Chroust (1973), 1.145-54, 185 (summer or early autumn 323); Schmitt (1992), 57; Natali (2013), 60-4.

${ }^{36}$ Bosworth (1988), 220; Worthington (2015), 95. [D.] 17, a non-Demosthenic Assembly speech (with a setting of c. 331), may give a sense of likely views about Macedonian infringements held on the reactionary wing of the political mainstream by the 320 s, even if it is a later work.

${ }^{37}$ Errington (1975), 55-7 and Bosworth (1988), 226, on Habicht (1957) 156-64, no. 1 (both dating the episode shortly after); cf. Schmitt (1992), 48-9 (shortly before). 
influence of the other state was relevant to the situation. ${ }^{38}$ Finally, as we saw earlier, Demosthenes' involvement in Anaxinus' arrest and death under torture - and, importantly, his apparent avoidance of any public repercussions, which must have meant he had the demos on his side - may also have occurred in about 341 against a background of mutual geopolitical antagonisms by Philip and Athens which were leading fairly inexorably towards the war declaration a year or so later.

Demosthenes also returned to Athens from self-imposed exile at the end of 323, after participating spontaneously in Athenian embassies in the Peloponnese and winning an official recall for doing so. ${ }^{39}$ Possible scenarios for Nicanor's killing can therefore now emerge, depending on whether he was the victim of a murder or a quasi-official process. If the latter, this may well have taken place after Demosthenes' return. If the former, it could have taken place either before or after. Even when away, he had clearly remained in touch with the outside world, ${ }^{40}$ such that if Nicanor was killed as early as the summer and his killers' case came to trial only somewhat later (after Demosthenes' return), the killing could easily have been represented in Athens at the time as 'ordered by Demosthenes from his hideout' or similar.

${ }^{38}$ Examples: Peithias in Corcyra in 427 (Thuc. 3.70.3-6); Anthemocritus at Megara in 432/1 ([D.] 12.4; Plut. Per. 30.3-4; Paus. 1.36.3); Aesion or Agaesion (?) in Iulis in about 364 or 363 (Rhodes and Osborne (2003), $198=$ no. 39, lines 33-41). Compare alleged Athenian maltreatments of the herald Nicias and envoy Amphilochus in the run-up to war with Philip in 340 ([D.] 12.2-3).

${ }^{39}$ Demosthenes' return: Plut. Dem. 27.6-8. Diodorus (18.13.6) seems to err on the timing; see Schaefer (1885-7), 3.374 and Worthington (2013), 332. His official recall: Plut. Dem. 27.3-6. ${ }^{40}$ As Plut. Dem. 26.7 and the (probably) genuine items among Demosthenes' Letters make clear. 
There are reasons to think, then, that the Nicanor incident did occur in the way and with the personnel described, and that it did come to court, but that the charges (as far as Demosthenes' involvement was concerned) were perhaps not especially serious, and that against the backdrop of the Lamian War, the killing of an admittedly high-profile former envoy would be at least not surprising. Our sources for the Lamian War period itself are not detailed enough for us to be confident that we should expect to find such an event mentioned in them. Finally, there is no special reason to identify Nicanor the envoy with any of the other Nicanors on offer, so equally no impediment to suggesting that he did leave the historical scene in the way I have suggested. Even if the envoy is not the right Nicanor, the preponderance of Macedonians and northern Greeks in our evidence for bearers of the name still invites my chosen chronological context for the killing.

\section{III}

If the trial of Demosthenes and Nicanor's killers can be dated to 323/2, what might that say about the period of the Rhetoric's composition? Two broad schools of thought about the genesis of the work currently hold the field. The first - a broad consensus - sees the work as developed by Aristotle over a long period, ${ }^{41}$ during which some parts were used in his teaching. It was probably begun as early as the 350s, during Aristotle's first period of residence in Athens (367-348/7). ${ }^{42}$

\footnotetext{
${ }^{41}$ For a good summary: Chiron (2011), 241-3.

${ }^{42}$ For summary: Kennedy (2007), 4-6; Chiron (2007), 44-5. For the idea of the 'early core', in use in the 350s: Rist (1989), 85-6, 137-44, 283. See Fortenbaugh (1996) for other sections composed in the 350s, some of which he sees as revised in the 340s, others incorporated less perfectly.
} 
Proponents of this view have also often used what has been thought to be the latest historical reference in the Rhetoric (Alexander's renewal of the Common Peace underpinning the League of Corinth in $336^{43}$ ) to draw the broad conclusion that the work reached its present form (or something not far off that) in the second period of Aristotle's residence in Athens (335/4-323), and most have preferred an earlier date in that range (i.e. mid-330s down to 330). ${ }^{44}$ This may be correct for much of the Rhetoric as we have it. But the reinterpretation of the Nicanor passage offered above, recommending a date in $323 / 2$ for the killing, would suggest that this part of 2.23 .3 at least belongs either to the last year or so of Aristotle's life (323-autumn 322) or, more probably, to the years after his death. That then opens up the question whether any of what surrounds this passage should be considered in similar terms.

If additions to the Rhetoric were taking place well beyond the traditional confines of the core composition period of the 330s, this may lend support to the second school of thought about the Rhetoric's composition: that the work was subject to very significant later editing and supplementation by those who had access to it, both members of Aristotle's school and subsequent

${ }^{43}$ The Common Peace renewal: Rhet. 2.23 .18 (1399b12-13) with Rapp (2002), 1.180. Caution is advisable on this date, though, because the term 'Common Peace' appears a good deal in fourthcentury sources: see Ryder (1965), xi-xii for a list. This instance may refer to the King's Peace of $387 / 6$, given that it comes after a reference to 'giving earth and water'.

${ }^{44}$ In general on the dating and development of the Rhetoric, see Rapp (2002), 1.178-93 and 31419; Rist (1989), 85-6, 142, 286 (dating the 'revised Rhetoric' to 333); Kennedy (1991), 301-5. Spengel (1851), 41-2 confidently dates the Rhetoric c. 330, cf. also Chiron (2011), 243. 
readers and redactors. ${ }^{45}$ (I say 'very significant' here because some who belong to the first school of thought are prepared to see additions and editorial intrusion of some order in the period after Aristotle's death and leading up to Andronicus' first-century edition. ${ }^{46}$ ) But it also indicates a possibility that the parts of the Rhetoric which consist mainly in the illustration of particular features with grouped examples were intended by Aristotle as, or else simply became, more 'open' sections of text, available for supplementation and revision by those with access to the work.

As we saw above, Aristotle apparently left Athens quite soon after the outbreak of the Lamian War, leaving his school (and presumably his teaching materials) in the hands of Theophrastus. ${ }^{47}$ If I am right to posit this period as the context for the Nicanor episode, then, it probably makes sense to attribute 2.23.3 to a member of Aristotle's school adding examples to this part of the topoi section at a later date, given that Aristotle himself may well have had other priorities before departure. It is also possible that the killing of Nicanor had not yet taken place, or that it had but that the killers (and Demosthenes) had not yet been brought to trial. This timeframe accords with the fact that the three historical references traditionally identified as the latest ones in the work all fall in the two connected chapters 2.23 and 2.24 along with the Nicanor passage. These are the reference to a Common Peace (dated to 336), Demades' comment about Demosthenes'

45 See Grayeff (1974), 69-85 and notably McAdon (2006a) and (2006b), 410-14 and 418-21. McAdon's conclusions have been challenged by Walzer and Inabinet (2011), especially his view that Strabo's account of the fate of Aristotle's works is exaggerated; but see Primavesi (2007) and Lord (1986), 140-5, 157-9 for valuable working modifications of Strabo's account.

${ }^{46}$ See e.g. Fortenbaugh (1991), 155-6 and Lord (1986), 157-8.

${ }^{47}$ Strabo Geog. 13.1.54; Kennedy (2007), 306-7; Lord (1986), 140; Chroust (1973), 1.219. 
influence (made after 338 , but, it should be added, potentially as late as $322^{48}$ ), and a comment made by a Macedonian envoy at Thebes (in 339) ${ }^{49}$ This notable clustering validates the idea that these two chapters may have been especially open to the addition of choice examples at a late stage or later stages, whether by Aristotle's design or not. ${ }^{50} \mathrm{~A}$ key point of interest is that the phrasing of the lead-in to 2.23 ( $\pi \alpha \rho \alpha \sigma \eta \mu \alpha$ ivó $\mu \varepsilon v o 1,2.22 .17 ; 1397 \mathrm{a} 2$ ) has been thought by Kennedy and others to indicate that the 2.23-24 unit is a supplement added in the later stages of the Rhetoric's formation: indeed some have used it as part of the reasoning for placing Book 2 in the mid-330s to conform with the apparent early-to-mid-330s context of the three historical references given

48 'After 338': Rapp (2002), 1.180, 785. The period immediately after Chaeronea is certainly an option, but 335 (Alexander's demand that Athens surrender its leading anti-Macedonian orators), is a possibility; Demades may have criticized Demosthenes for getting Athens into this situation in the first place. Parallels with Aeschines' Against Ctesiphon (of 330) $(3.57,147,188,226,253$ ) may point to a later date. A good later context could be Antipater's similar demand after Athens's defeat in 322; Demades proposed the decree condemning Demosthenes, Hyperides, and the others to death: Brun (2000), 118-19. In the debate, he could easily have criticized Hyperides' and others' roles in precipitating the Lamian War by analogy with Demosthenes' role the previous decade. ${ }^{49}$ Rhet. 2.23 .18 (1399b12-13), 2.24 .8 (1401b32-34), and 2.23.6 (1397b31-98a3).

${ }^{50}$ The issue of the composition and organization of the specific topoi headings in the catalogues themselves is treated by Rambourg (2014), 223-56. I am only interested here in how examples or groups of examples might have accrued (or have been added or replaced) under those headings. 
above. ${ }^{51}$ My suggested re-dating would preserve the significance of $\pi \alpha \rho \alpha \sigma \eta \mu \alpha \imath$ ó $\mu \varepsilon v o 1$, but would push the section's organization in its present form much later. All this should be qualified, though, by allowing that $\pi \alpha \rho \alpha \sigma \eta \mu \alpha i v o ́ \mu \varepsilon v o r$ itself can have other meanings, ${ }^{52}$ and that no robust or systematic means has yet emerged which would allow us to determine how or how far individual parts of the Rhetoric like the transitions might or might not reflect post-Aristotelian as opposed to Aristotelian composition.

It is nonetheless interesting that the last two sentences of 2.23.3 as a specific unit (1397b711, i.e. the Nicanor passage plus the example of an undated trial about the killing of an unnamed man at Thebes ${ }^{53}$ ) have attracted the attention of those establishing the text of the work. Spengel thought them a late addition by Aristotle, perhaps a badly-integrated marginal note. ${ }^{54}$ Kassel

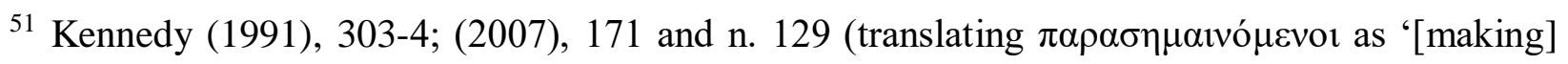
these things clear in a supplementary discussion'). He opts for a 336 or 335 date for the addition, as does Chiron (2007), 52-4; cf. Düring (1957), 258-9; (1966), 52, 118, 124, 143-4. Also on 2.2324 as a late addition, from various angles: e.g. Chroust (1973), 1.350 n. 59; Rapp (2002), 1.180-1 and n. 52 (without special endorsement); Fortenbaugh (1991), 152 n. 1. On other proposed late additions to Book 2: Kennedy (1991), 303-4; Fortenbaugh (1996), 175-80 and 185-7; and McAdon (2006b), 410-14 with n. 23.

${ }^{52}$ Grimaldi (1988), 290.

${ }^{53}$ This could be Euphron's murder in (366 or) 365 (Xen. Hell. 7.3.4-12): Kassel (1976), 127; Grimaldi (1988), 298; also Rambourg (2014), 273 (with greater certainty, based on Hell. 7.3.9). ${ }^{54}$ Spengel (1851), 47 (cf. (1867), 2.296). See Rapp (2002), e.g. 1.181 on Aristotle's additions. Rist (1989), 86, 161, 206 comments that Aristotle typically added 'not lines but chunks of text'. 
double-brackets them and reports Spengel's view that they ought to be moved back to follow 1397a27, ten lines back in Kassel's text, and also Diels' view that they are a loose supplement (one of a number he locates in Aristotle's texts) referring to content eight lines back. Spengel also proposed further rearrangement earlier in 2.23.3. ${ }^{55}$ These proposed transpositions seem plausible, but the more general scholarly disquiet may indicate that this section's inconcinnities are simply particularly visible markers of a broader phenomenon: a potentially multi-stage, and potentially piecemeal, addition and arrangement of examples within the catalogues of topoi, whether carried out by Aristotle or not. ${ }^{56}$ If it is right to see 2.23 and 2.24 as somehow 'supplementary', and late in date, it follows that 2.23 and 2.24 , and not just 2.23.3, could be candidates for identification either as late additions by Aristotle or, perhaps, as sections which were either intended to attract, or ended up attracting, further examples when those with access to the text chose to add them.

\section{IV}

My conclusion, then, is as follows. If we hypothesize that Nicanor was killed between early 323 (the time of the last sources likely to mention such an event) and autumn 322 (the time of Demosthenes' flight and death), then a possible solution to the conundrum posed by Rhetoric 2.23.3 (1397b7-9) emerges: Demosthenes was implicated by his political adversaries in Nicanor's killing (as he had been in the murder of Nicodemus and the killing of Anaxinus years earlier), but was able to avoid the charge relatively easily, perhaps because it was as baseless as many other

\footnotetext{
${ }^{55}$ Kassel (1976), 127; Spengel (1851), 46-7; Diels (1886), 10 n. 1; see also Rapp (2002), 2.753.

56 Trevett (1996), 375 (Aristotle added examples 'piecemeal... as they came to his attention').
} 
charges against the anti-Macedonians had been over the preceding fifteen years, but probably also because the broader context was against his accusers. As I have suggested, a likely timing is later 323 (or early 322), around or after the outbreak of the Lamian War, a period when an Athenian jury might well welcome the removal of a Macedonian - especially if this Nicanor was the former bearer of the Exiles Decree and thus a physical symbol of Macedonian hegemony - and therefore be less inclined to punish his killers.

If so, there are repercussions for the dating of this part of the Rhetoric (as well as for the stability of the idea that the whole work had a 'final' date). The later date thus arrived at for 2.23.3 not only dovetails with the late date others have inclined to for 2.23-24 but pushes it much later than the traditionally preferred period of the mid-to-late 330s, giving support to the possibility that these sections reached their current form after Aristotle's death and thus opening up the possibility that larger sections of the work may have done so too. The reconstruction I have sketched must

remain speculative, but the conventional understandings of the character of the Rhetoric's references to Demosthenes, of the identity of Nicanor the envoy, and of the work's latest internal dates, are much more precarious than has previously been allowed. Therefore, alternative interpretations of them are possible, and a reconstruction which puts faith in the accuracy of the author or authors of 2.23.3, and also intersects with scholarly concerns about the compositional status of this part of Book 2, recommends itself as a legitimate exercise.

\section{BIBLIOGRAPHY}

Ashton, N. G. (1983), ‘The Lamian War - A False Start?', Antichthon 17: 47-63

Berve, H. (1926), Das Alexanderreich auf prosopographischer Grundlage (Munich)

Bosworth, A. B. (1988), Conquest and Empire: the Reign of Alexander the Great (Cambridge) 
Bosworth, A. B. (1994), 'A New Macedonian Prince', $C Q$ 44: 57-65

Brun, P. (2000), L’orateur Démade: essai d'histoire et d'historiographie (Pessac)

Carey, C. (2000), Aeschines (Austin)

Chiron, P. (2007), Aristote: Rhétorique (Paris)

Chiron, P. (2011), 'Relative Dating of the Rhetoric to Alexander and Aristotle's Rhetoric: A Methodology and Hypothesis', Rhetorica 29: 236-62

Chroust, A.-H. (1973), Aristotle: New Light on his Life and on Some of his Lost Works (London)

Cope, E. M. (1877), The Rhetoric of Aristotle (rev. and ed. J. E. Sandys) (Cambridge)

Diels, H. (1886), Über das dritte Buch der aristotelischen Rhetorik (Berlin)

Düring, I. (1957), Aristotle in the Ancient Biographical Tradition (Göteborg)

Düring, I. (1966), Aristoteles: Darstellung und Interpretation seines Denkens (Heidelberg)

Errington, R. M. (1975), 'Samos and the Lamian War', Chiron 5: 51-7

Fisher, N. R. E. (2001), Aeschines: Against Timarchos (Oxford)

Fortenbaugh, W. W. (1991), 'Persuasion through Character and the Composition of Aristotle's Rhetoric', RhM 134: 152-6

Fortenbaugh, W. W. (1996), 'On the Composition of Aristotle's Rhetoric', in C. MuellerGoldingen and K. Sier (eds.), Lenaika: Festschrift für Carl Werner Müller zum 65. Geburtstag (Stuttgart): 165-88

Freese, J. H. (1926), Aristotle: The 'Art' of Rhetoric (Cambridge MA/London)

Grayeff, F. (1974), Aristotle and his School (London)

Grimaldi, W. M. A. (1988), Aristotle, Rhetoric II: A Commentary (New York)

Habicht, C. (1957), 'Samische Volksbeschlüsse der hellenistischen Zeit', MDAI(A) 72: 152-274

Hansen, M. H. (1999), The Athenian Democracy in the Age of Demosthenes (2 ${ }^{\text {nd }}$ ed.) (London) 
Heckel, W. (2006), Who's Who in the Age of Alexander the Great (Malden MA/Oxford)

Heckel, W. (2007), 'Nicanor Son of Balacrus', GRBS 47: 401-12

Kassel, R. (1976), Aristotelis Ars Rhetorica (Berlin)

Kennedy, G. A. (1991), Aristotle: On Rhetoric: A Theory of Civic Discourse (Oxford)

Kennedy, G. A. (2007), Aristotle: On Rhetoric: A Theory of Civic Discourse (2 ${ }^{\text {nd }}$ ed.) (Oxford)

Landucci Gattinoni, F. (2008), Diodoro Siculo: Biblioteca storica: Libro XVIII (Milan)

Lord, C. (1981), 'The Character and Composition of Aristotle's Politics', Political Theory 9: 45978

Lord, C. (1986), 'On the Early History of the Aristotelian Corpus', AJP 107: 137-61

McAdon, B. (2006a), 'Strabo, Plutarch, Porphyry and the Transmission and Composition of Aristotle's Rhetoric: A Hunch', RSQ 36: 77-105

McAdon, B. (2006b), 'The Special Topics in the Rhetoric: A Reconsideration', RSQ 36: 399-424

Meerwaldt, J. (1926), 'De Aristotelis erga Demosthenem animo', Mnemosyne 54: 348-69

Natali, C. (2013), Aristotle: His Life and School (ed. D. S. Hutchinson) (Princeton)

Primavesi, O. (2007), 'Ein Blick in den Stollen von Skepsis: Vier Kapitel zur frühen Überlieferung des Corpus Aristotelicum', Philologus 151: 51-77

Rambourg, C. (2014), Topos: Les premières méthodes d'argumentation dans la rhétorique grecque des $V^{e}-I V^{e}$ siècles (Paris)

Rapp, C. (2002), Aristoteles: Rhetorik (Berlin)

Rhodes, P. J. and R. G. Osborne (2003), Greek Historical Inscriptions 404-323 BC (Oxford)

Rist, J. M. (1989), The Mind of Aristotle: a Study in Philosophical Growth (Toronto/London)

Roisman, J. (1993), The General Demosthenes and his Use of Military Surprise (Stuttgart)

Ryder, T. T. B. (1965), Koine Eirene (London) 
Schaefer, A. (1885-7), Demosthenes und seine Zeit (2 ${ }^{\text {nd }}$ ed., 3 vols.) (Leipzig)

Schmitt, O. (1992), Der Lamische Krieg (Bonn)

Spengel, L. (1851), Über die Rhetorik des Aristoteles (Munich)

Spengel, L. (1867), Aristotelis Ars Rhetorica (Leipzig)

Stylianou, P. J. (1998), A Historical Commentary on Diodorus Siculus, Book 15 (Oxford)

Tataki, A. B. (1998), Macedonians Abroad: a Contribution to the Prosopography of Ancient Macedonia (Athens)

Trevett, J. C. (1996), 'Aristotle's Knowledge of Athenian Oratory', CQ 46: 371-9

Tuplin, C. J. (1979), 'Two Proper Names in the Text of Diodorus, Book 15', CQ 29: 347-57

Walzer, A. E. and B. M. Inabinet (2011), 'Who Wrote the Rhetoric? A Response to Brad McAdon', Advances in the History of Rhetoric 14: 166-90

Westlake, H. D. (1968), Individuals in Thucydides (Cambridge)

Whitehead, D. (2000), Hypereides: The Forensic Speeches (Oxford)

Worthington, I. (1992), A Historical Commentary on Dinarchus (Ann Arbor)

Worthington, I. (2002), 'Who is the Demosthenes at the End of Demosthenes 56, Against Dionysodorus? An Exercise in Methodology', Scholia 11: 18-24.

Worthington, I. (2006), Demosthenes: Speeches 60 and 61, Prologues, Letters (Austin)

Worthington, I. (2013), Demosthenes of Athens and the Fall of Classical Greece (Oxford)

Worthington, I. (2015), 'From East to West: Alexander and the Exiles Decree', in P. Wheatley and E. Baynham (eds.), East and West in the World Empire of Alexander (Oxford): 93-106 